\title{
Research results of agrotechnical indicators of universal seed-fertilizer stubble drill SZS-4U
}

\author{
S. I. Kambulov ${ }^{1,2, *}$, I. V. Bozhko ${ }^{1}$, A. A. Boyko², D. S. Podlesniy ${ }^{2}$, and L. A. Vodianitskaya ${ }^{2}$ \\ ${ }^{1}$ Federal State-Founded Scientific Establishment “Agricultural research center “Donskoy”, 14 Lenina \\ Street, Zernograd, 347740, Russia \\ ${ }^{2}$ Don State Technical University, 1 Gagarina Square, Rostov-on-Don, 344000, Russia
}

\begin{abstract}
Abstact. As known, seed drills are the most complex agricultural machines in terms of the performed technological process since they include a number of sequentially or concurrent operations. The modern crop farming technologies shall include practices that improve soil fertility through the application of organic and mineral fertilizers. Sustainable crop production is carried out with environmentally friendly and economically competitive farming methods. The object of this paper is to determine the main agrotechnical parameters of universal seed-fertilizer stubble drill SZS-4U. The research methodology has involved determination of the main agrotechnical parameters of the seeder. Based on the research results it was found that the uneven seeding of winter and spring wheat at two speed modes was $2,98 \%$ and $3,04 \%$, for spring barley is was $2,70 \%$ and $3,00 \%$, mineral fertilizers $-7,57 \%$ and $7,69 \%$. With the optimum depth of the openers, the actual depth of seeds placement of spring wheat was 56,5 and $48,9 \mathrm{~mm}$, winter wheat $-44,5$ and $43,9 \mathrm{~mm}$, spring barley $-48,0$ and 44,3 $\mathrm{mm}$, these data meets a given depth of seeding. After SZS-4U has passed there's been retained 68,12 - 72,38 percent (\%) of stubble on unprepared or minimally prepared grounds, and these values meet agrotechnical requirements which stipulate at least $65 \pm 10 \%$. Thus, we can conclude that the universal seed-fertilizer stubble drill SZS-4U meets all agrotechnical requirements and stipulated indicators in terms of sowing winter wheat, spring barley, and spring wheat with simultaneous fertilization.
\end{abstract}

\section{Introduction}

The modern crop farming technologies shall include practices that improve soil fertility through the application of organic and mineral fertilizers. Sustainable crop production is carried out with environmentally friendly and economically competitive farming methods. Such results are possible to achieve through both economically feasible and environmentally responsible farming technology that ensures soil conservation [1]. Therefore, while designing a seed drill the application of fertilizers and mulching of soil with crop residues shall be considered to obtain high crop yields. [2].

As known, seed drills are the most complex agricultural machines in terms of the performed technological process since they include a number of sequentially or concurrent

* Corresponding author : kambulov.s@mail.ru 
operations. Generally, those are the following operations: a selection of seeds from the hopper by a seed-sowing device, formation of a seed flow outgoing from a seed-sowing device, transportation of seeds through the seed drill tube to the opener, formation of the seed furrow and seedbed, placement and distribution of seeds along the furrow, covering of seeds with special coverers, coulters (disc or chisel type) as well as smoothing and mulching the field surface.

Each of the operations, in turn, influences the quality of an overall technological process. Cropping capacity is achieved through an optimal combination of the number of plants per unit area and the productivity of one plant, so, it all comes to optimization of size and configuration of a feeding area. Thus, the uneven seeding is one of the main indicators of the quality of seed drill operation. The increase in yield is conditioned by the ability of the crop root system to make the best use of nutrients from different soil horizons [3].

One of the main methods to achieve high grain yields is a seeding method and the technology of its implementation. The contemporary global practice of the creation of highly efficient and adapted to certain edaphoclimatic conditions seed drills is aimed at increasing the degree of combination of technological operations (multipurpose) of seeders [4]. The main disadvantage of modern seed drills is an insufficiently high quality of seeding, namely, non-fulfillment of the requirements for uneven seeding between the openers of a seed drill and a decrease in seeding depth. In addition, modern farming methods require continuously in-depth research of agricultural machinery engineering to ensure high-quality performance of technological operations, in particular the research of energy indicators of a seeder [5].

\section{Materials and methods}

The universal seed-fertilizer stubble drill SZS-4U (Fig. 1 and 2) is designed for raw sowing of seeds of grain and grain legumes on a minimally prepared ground with simultaneous fertilization and seed covering in the sown rows. The drill can also be used for seeding on a prepared ground while the front ripple-edge discs (coulters) are fixed in the transport position [6-7]. The SZS-4U seeder is a trailed-type hydraulic machine and can be mated to tractors of 1,4-2 drawbar categories in a single-seed drill and to tractors of 3-5 drawbar categories in multi-seed drills with hydraulic hookup units.

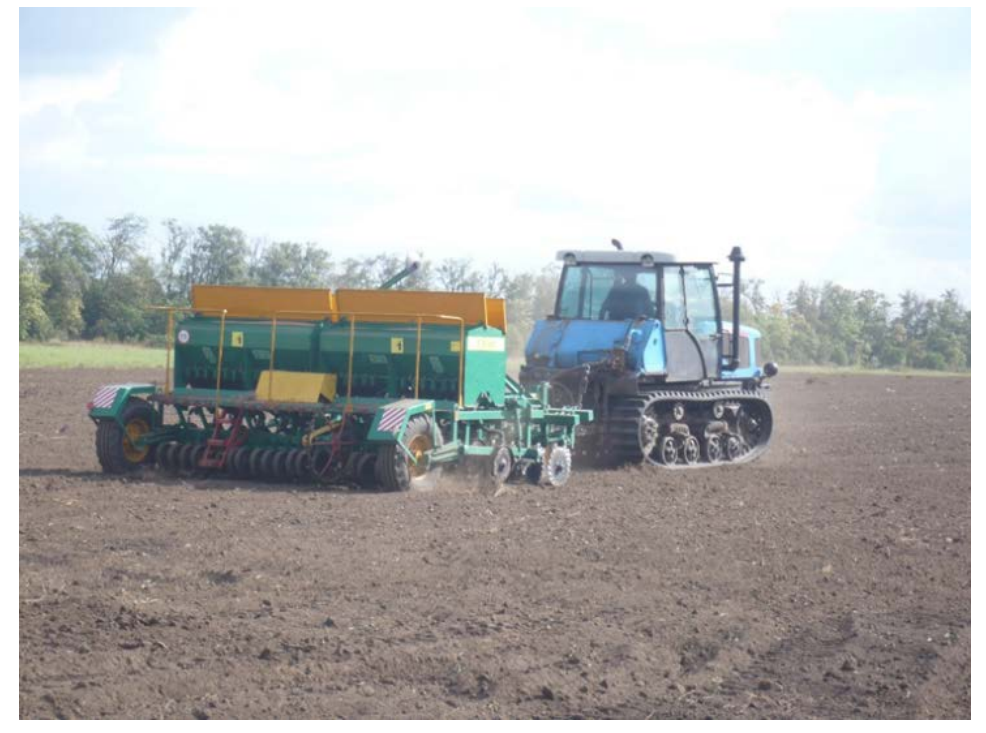

Fig. 1. The universal seed-fertilizer stubble drill SZS-4U in operation. 


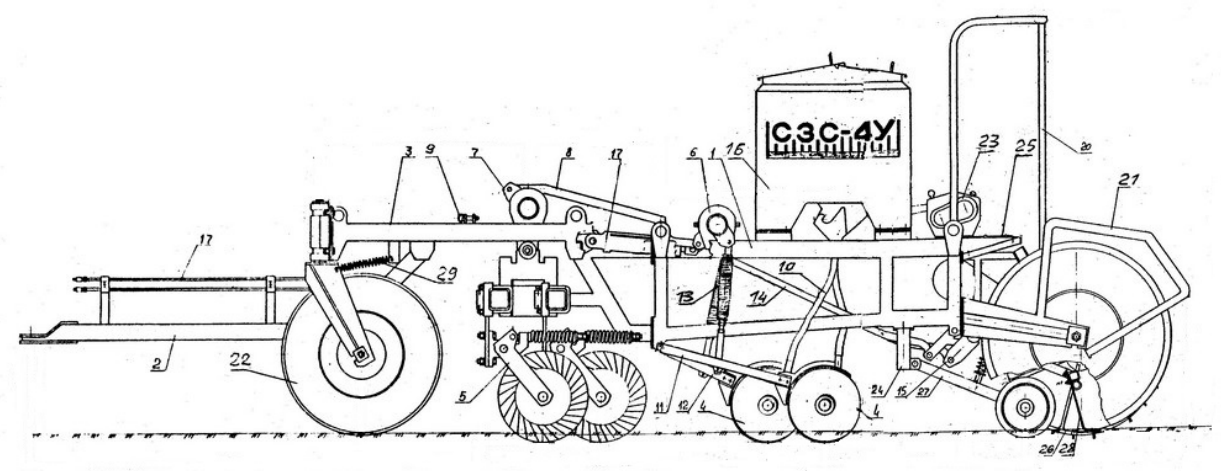

1 - seeder frame; 2 - hitch frame; 3 - coulter frame; 4 - openers; 5 - coulters;

6 - main drive shaft; 7 - coulter shaft; 8 - coulters draw bar; 9 - pin lock;

10 - seed drill tube; 11 - long bracket; 12 - short bracket; 13 - opener rod;

14 - lifting draw bar; 15 - rear shaft; 16 - grain and fertilizer box; 17 - hydraulic drive; 20 - handrail; 21 - rear support-drive wheel; 22 - front support-drive wheel; 23 - reduction gear box; 24 - surface adjusting device; 25 - platform; 26 - driving wheel; 27 - seed press wheel; 28 - coverer; 29 - spring

Fig. 2. Design of universal stubble seed drill SZS-4U

The main feature of the seed drill is ripple-edge discs - coulters which enable the drill to operate on an unprepared ground (zero soil treatment technology) or on a minimally prepared ground with a large number of crop residues [8].

The research methodology has involved a determination of main agrotechnical parameters of the seeder, namely: an uneveness of seeding and imprecision of sowing, seed cracking, an average depth of seed covering at a maximum depth of openers, an average depth of seed covering at a minimum depth of openers, an average depth of seed covering at an optimum depth of openers, depth of placement of fertilizers, the quantitative proportion of seeds planted at a given depth, the height of furrow slices after the drill has passed, the number of seedlings and relative field germination, as well as the preservation of stubble and changes in the content of erosion threatening particles [9-10].

\section{Research results}

The technological process of the drill operation is as follows: the seeds filled in the grain sections of grain-fertilizer containers and fertilizers filled into fertilizer containers flow under gravity to fill boxes of grain and fertilizer planting units. When the drill moves with coulters and openers lowered in operating position, the rollers of grain and fertilizer planting units are set in motion by the drive wheel through the reduction gearbox. While rotating they capture the seeds and fertilizers, throw them into the seed funnels. Seeds and fertilizers enter the openers through the seed tubes, roll down the tube and fall to the bottom of the furrows formed by the opener discs in the soil after the coulter discs have passed. The covering of seeds and fertilizers is done by natural shedding of the soil from the furrow walls. The press rollers following the coulters compact the soil over the seeds and fertilizers, and following them coverers loosen and level the topsoil.

Research on determination of agrotechnical indicators of the universal seed-fertilizer stubble drill SZS-4U were carried out on sowing winter wheat, spring barley and spring wheat with simultaneous fertilization. 
The research conditions were characterized by the following indicators: the filed relief is even, the microrelief (cross) is weakly expressed 1,6-2,17 cms. The moisture content of the soil at the depth of planting seeds of spring wheat is $28,68 \%$, of spring barley $-19,44 \%$, and of winter wheat $-16,76 \%$. So, the moisture content was within the normal range $(15-25 \%$, $18-30 \%$ ) and meets agrotechnical requirements. Soil firmness at the seeding depth was $0,28-$ $0,78 \mathrm{MPa}$, which is above the standard (in the $0-5 \mathrm{~cm}$ horizon it shall be within $0,05-0,15$ MPa and that of 0,15-0,45 MPa in 5-10 cm horizon). The depth of the loosened soil layer on the prepared ground was $12,45 \mathrm{~cm}$ for spring wheat sowing, 7,56 cm for spring barley sowing, and 8,01 cm for winter wheat sowing [11].

The crumbling quality of the loosened soil layer is good, the fractions ranging in size from 0 to $10 \mathrm{~mm}$ are up to 70,38-71,07\%. Weeds were absent in the fields. On unprepared grounds, the length of winter wheat and sunflower stubble was $22,75 \mathrm{~cm}$ and $23,83 \mathrm{~cm}$, respectively, so in compliance with agrotechnical requirements. Thus, the research was carried out on grounds extreme in firmness. The rest conditions corresponded to the agrotechnical requirements. The main agrotechnical indicators are shown in Table 1.

Table 1. Main agrotechnical parameters of the universal seed-fertilizer stubble drill SZS-4U

\begin{tabular}{|c|c|c|c|c|c|c|}
\hline Indicator & \multicolumn{6}{|c|}{ Indicatorvalue } \\
\hline Crop, Variety & \multicolumn{2}{|c|}{$\begin{array}{c}\text { SpringWheat } \\
\text { "DonskayaElegia» }\end{array}$} & \multicolumn{2}{|c|}{$\begin{array}{l}\text { SpringBarley } \\
\text { "Priazovskyi-9" }\end{array}$} & \multicolumn{2}{|c|}{$\begin{array}{c}\text { WinterWheat } \\
\text { "Rostovchanka-3" }\end{array}$} \\
\hline Type of fertilizer & \multicolumn{6}{|c|}{ AmmoniumNitrate } \\
\hline $\begin{array}{l}\text { Speed m/s } \\
(\mathrm{km} / \text { hour })\end{array}$ & $\begin{array}{c}2,74 \\
(9,86)\end{array}$ & $\begin{array}{c}3,33 \\
(12,0)\end{array}$ & $\begin{array}{c}2,83 \\
(10,20)\end{array}$ & $\begin{array}{c}3,33 \\
(12,0)\end{array}$ & $\begin{array}{c}2,69 \\
(9,70)\end{array}$ & $\begin{array}{c}3,23 \\
(11,62)\end{array}$ \\
\hline Gearratio & \multicolumn{2}{|c|}{0,616} & \multicolumn{2}{|c|}{0,616} & \multicolumn{2}{|c|}{0,616} \\
\hline $\begin{array}{c}\text { Uneven seeding between units, \%: } \\
\text { - for grain crops } \\
\text { - formineralfertilizers }\end{array}$ & $\begin{array}{l}2,98 \\
7,57\end{array}$ & $\begin{array}{l}3,04 \\
7,69\end{array}$ & $\begin{array}{l}2,70 \\
\text { Idem }\end{array}$ & $\begin{array}{l}3,00 \\
\text { idem }\end{array}$ & $\begin{array}{l}2,98 \\
\text { idem }\end{array}$ & $\begin{array}{c}3,04 \\
\text { idem }\end{array}$ \\
\hline $\begin{array}{l}\text { Imprecision of overall sowing, \% } \\
\text { for grain crops } \\
\text { - form ineral fertilizers }\end{array}$ & $\begin{array}{l}0,48 \\
1,05\end{array}$ & $\begin{array}{l}0,51 \\
1,21\end{array}$ & $\begin{array}{l}0,40 \\
\text { Idem }\end{array}$ & $\begin{array}{r}0,48 \\
\text { idem }\end{array}$ & $\begin{array}{r}0,48 \\
\text { idem }\end{array}$ & $\begin{array}{c}0,51 \\
\text { idem }\end{array}$ \\
\hline Seedcracking, \% & - & 0,28 & - & 0,16 & - & 0,28 \\
\hline $\begin{array}{l}\text { the average depth of seed covering at the } \\
\text { maximum depth of the openers, } \mathrm{mm}\end{array}$ & 80,5 & idem & 80,3 & idem & 80,1 & idem \\
\hline $\begin{array}{l}\text { the average depth of seed covering at the } \\
\text { minimum depth of the openers, mm }\end{array}$ & 37,4 & idem & 39,3 & idem & 39,5 & idem \\
\hline $\begin{array}{l}\text { the average depth of seed covering at the } \\
\text { optimum depth of the openers: } \\
\text {-given depth, mm } \\
\text {-average depth, mm } \\
\text {-standard deviation, mm } \\
\text { - coefficient of variability, \% }\end{array}$ & $\begin{array}{c}40 \ldots 60 \\
56,5 \\
13,1 \\
23,32\end{array}$ & $\begin{array}{c}40 \ldots 60 \\
48,9 \\
18,7 \\
38,32\end{array}$ & $\begin{array}{c}40 \ldots 60 \\
48,0 \\
14,6 \\
30,46\end{array}$ & $\begin{array}{c}40 \ldots 60 \\
44,3 \\
11,4 \\
25,80\end{array}$ & $\begin{array}{c}40 \ldots 60 \\
44,5 \\
11,2 \\
27,68\end{array}$ & $\begin{array}{c}40 \ldots 60 \\
43,9 \\
12,8 \\
28,81\end{array}$ \\
\hline the depth of placement of fertilizers, mm & \multicolumn{6}{|c|}{ At the depth of seeding } \\
\hline $\begin{array}{l}\text { Quantitative share of seeds covered at a } \\
\text { given depth, } \pm 1 \mathrm{~cm}, \%\end{array}$ & 78,4 & 73,3 & 79,3 & 76,5 & 79,0 & 75,2 \\
\hline $\begin{array}{c}\text { The number of seeds not covered in the soil, } \\
\text { pcs/sq.m. } \\
\text { Including those on the wheel track of the } \\
\text { seed drill }\end{array}$ & \multicolumn{6}{|c|}{0} \\
\hline The number of seedling, pcs/sq.m. & 610,0 & 593,0 & 413,3 & 409,75 & 447,7 & 404,0 \\
\hline Relative field germination, $\%$ & 91,1 & 88,3 & 81,53 & 80,5 & 79,4 & 71,8 \\
\hline $\begin{array}{l}\text { The height of furrow slices after the drill has } \\
\text { passed, cm }\end{array}$ & 2,01 & 2,36 & 3,04 & 2,37 & 3,50 & 2,80 \\
\hline Stubble retention, \% & - & - & 68,12 & 71,39 & 72,38 & 70,48 \\
\hline $\begin{array}{c}\text { Changes in the content of erosion threatening } \\
\text { particles, } \%\end{array}$ & $+1,62$ & $+1,7$ & $+2,27$ & $+2,36$ & $+3,09$ & $+2,94$ \\
\hline
\end{tabular}


Research for determination of agrotechnical indicators of the universal seed-fertilizer stubble drill SZS-4U were carried out at two speed modes. While sowing spring wheat, the seed drill was working without coverers, while sowing spring barley - without coulters, and while sowing winter wheat the drill was completely packaged. When adjusting the seed drill to the farm seeding rate of wheat seeds, the gear ratio was 0,616 , and the length of the working unit of the seed roller was $26 \mathrm{~mm}$; for barley seeds, the length of the working unit of the seed roller was $30 \mathrm{~mm}$ (maximum opening) at the same gear ratio. The quality of sowing seeds of winter wheat, spring wheat, spring barley and fertilizers at the farm seeding rate meets the agrotechnical requirements [12].

Thus, the uneven seeding of winter and spring wheat at two speed modes was $2,98 \%$ and $3,04 \%$, for spring barley it was 2,70\% and 3,00\%, mineral fertilizers $-7,57 \%$ and $7,69 \%$. According to agrotechnical requirements, the unevenness should not exceed $\pm 5 \%$ for seeds and $\pm 10 \%$ for fertilizers. Pertaining to the imprecision of overall seeding of winter and spring wheat $0,48 \%$ and $0,51 \%$, spring barley $0.40 \%$ and $0.48 \%$ and mineral fertilizers $1.05 \%$ and $1.21 \%$, the seed drill meets the agrotechnical requirements, that shall not exceed $\pm 3 \%$ for seeds and $\pm 10 \%$ for fertilizers. Pertaining to seeds cracking value of winter and spring wheat of $0.28 \%$, spring barley of $0,16 \%$, the SZS- $4 \mathrm{U}$ seed drill meets agrotechnical requirements that shall not exceed $0,3 \%$ cracking value.

According to the research results, the average depth of seed covering at the maximum and minimum depth of the openers on grounds was 80,5; 80,3; 80,1 and 37,4 mm; 39,3; 39,5 mm, respectively. With the optimum depth of the openers, the actual depth of seeds placement of spring wheat was 56,5 and $48,9 \mathrm{~mm}$, winter wheat $-44,5$ and $43,9 \mathrm{~mm}$, spring barley $-48,0$ and $44,3 \mathrm{~mm}$, these data meets a given depth of seeding. The standard deviation from the average seeding depth at different speed modes and grounds ranged from 11,2 to $18,7 \mathrm{~mm}$. The quantitative share of seeds placed at a given depth of $\pm 1 \mathrm{~cm}$ (compactness) varies in speed from 78,4 to $73,3 \%$ for spring wheat sowing, from 79,3 to $76,5 \%$ for spring barley sowing and from 79,0 to $75,2 \%$ for winter wheat sowing [13-14].

The height of furrow slices at speed modes for spring wheat sowing was 2,01 and 2,36 $\mathrm{cm}$, on sowing winter wheat it was 3,50 and $2,80 \mathrm{~cm}$, for spring barley sowing $-3,04$ and 2,37 cm. After SZS-4U has passed there has been retained 68,12 - 72,38 percent (\%) of stubble on unprepared or minimally prepared grounds, and these values meet agrotechnical requirements which stipulate at least $65 \pm 10 \%$. At the same time, the amount of erosion threatening particles content increases slightly from 1,62 to 3,09\%. The number of seedlings of spring wheat at different speed modes was 610,0 and 593,0 heads/sq.m, for spring barley it was 413,3 and 409,75 heads/sq.m., and for winter wheat $-447,7$ and 404,0 pcs/sq.m. The relative field germination on grounds was $91,1 \%$ and $88,3 \% ; 81,53 \%$ and $80,5 \% ; 79,4 \%$ and $71,8 \%$, respectively.

\section{Conclusion}

During experimental studies on sowing seeds of winter wheat, spring wheat, and spring barley with simultaneous fertilization, the universal seed-fertilizer stubble drill SZS-4U ensured technological process quality metrics established for seed-sowing devices, in particular in terms of imprecise seeding and uneven seeding. According to the research results, the average depth of seed covering at the optimum depth of the openers for spring wheat was 56,5 and 48,9 mm, winter wheat $-44,5$ and 43,9 mm, spring barley $-48,0$ and $44,3 \mathrm{~mm}$, these data meets a given depth of seeding. The standard deviation from the average seeding depth at different speed modes and grounds ranged from 11,2 to $18,7 \mathrm{~mm}$. The height of furrow slices at speed modes for spring wheat sowing was 2,01 and 2,36 cm, on sowing winter wheat it was 3,50 and $2,80 \mathrm{~cm}$, for spring barley sowing $-3,04$ and 2,37 cm. After SZS-4U has passed there's been retained 68,12 - 72,38 percent (\%) of stubble on unprepared 
or minimally prepared grounds, and these values meet agrotechnical requirements. Thus, we can conclude that the universal seed-fertilizer stubble drill SZS-4U meets all agrotechnical requirements and stipulated indicators in terms of sowing winter wheat, spring barley, and spring wheat with simultaneous fertilization.

\section{References}

1. Yang X, Chen X, Yang X 2019 Canadian Journal of Soil Science 991 pp $92-$ 99

2. Parkhomenko G, Parkhomenko S 2017 Khraneniye i pererabotka zerna 1209 pp 55-60

3. Pryshliak V 2017 Mechanization in Agriculture 2 pp 82-86

4. Aduov M, Nukusheva S, Kaspakov E, Isenov K, Volodya K, Tulegenov T 2019 Mechanization in Agriculture\& Conserving of the Resources 1 pp 25-26

5. Melnic I, Sclear P 2019 Mechanization in Agriculture\& Conserving of the Resources 3 pp 85-87

6. Burton G, Shend D, Cambell C 2014 Güotechnique Letters 42 pp 88-93

7. Parkhomenko S, Parkhomenko G 2016 Innovatsii v sel'skom khozyaystve 318 pp 40-47

8. Medvedev V, Slovinska-Yurkevich A, Brik M 2012 Gruntoznavstvo 13 1-2 pp 5-22

9. Parkhomenko G, Parkhomenko S 2016 Trudy GOSNITI 122 pp 87-91

10. Konrad J, Lebeau M 2015 Canadian Geotechnical Journal 5212 pp 2067-2076

11. Gao Y, Sun D, Zhu Z, Xu Y 2018 Acta Geotechnica pp 1-12

12. Demchuk E, Sabiev U, Myalo V, Chupin P, Koval' V 2019 Traktory i sel'khozmashiny 3 pp 12-18

13. Parkhomenko G, Kambulov S, Olshevskaya A, Babadzhanyan A, Gucheva N, Mekhantseva I, 2019 IOP Conf. Series: Earth and Environmental Science 403 012144 doi:10.1088/1755-1315/403/1/012144

14. Semenikhina Ju, Kambulov S, Parkhomenko G, Boyko A, Ponomareva S, Shvedova S, Koltsov A, and Tsybenko E 2020 E3S Web of Conferences 175 09008, https://doi.org/10.1051/e3sconf/202017509008 